\title{
Teaching Verb-Noun Collocations is to Kill Two Birds with One Stone
}

\author{
Fatemeh Ebrahimi-Bazzaz \\ Islamic Azad University, Tehran North Branch \\ The College of Foreign Languages, The Department of English Translation, Iran
}

\begin{abstract}
Collocations or more specifically verb-noun collocations are an sophisticated part of learning a second language or a foreign language; however, it is a crucial element of communicative competence. Native speakers' communicative competence consists of collocational competence which includes co-occurred words that English native speakers are subconsciously aware of their use. Additionally, any speech community has a set of idiomatic ways of uttering concepts in definite complete expressions and many phrase-frames. Hence, learning formulaic language may cause a great deal of problems for non-native speakers with deficient communicative competence. Henceforth, the objective of this paper is to discern the effect of treatment in teaching verb-noun collocations to 60 Iranian learners who took part in a collocation test. To reach this aim, an Independent Samples T-Test was run and the result showed there was no significant difference in scores of groups. Subjects were randomly distributed into control and experimental groups. After ten weeks of intervention, a paired-samples t-test was conducted to assess the impact of the treatment on students' scores on the Collocation Test. There was a statistically significant increase in the Collocation Test scores in control group $(M=49.87, S D=13.34)$ to experimental group $[M=52.54, S D=12.12, t(29)=-20.26, p<0.000]$. The results of the statistical analyses validate that teaching collocations explicitly and purposefully can assist Iranian students to learn verb-noun collocations better to converse efficiently with native speakers. It can be concluded the results have immediate implications for language learners and EFL instructors to teach in a ground-breaking method.
\end{abstract}

Keywords: Language learning, Verb-Noun Collocations, Communicative Competence, Iranian EFL learners

\section{INTRODUCTION}

Learning verb-noun collocations are important part of communicative competence. In this regards, many research studies on the knowledge for English as foreign language (EFL) learners have been performed. They had different cultural backgrounds and from different countries. Researchers have discovered that foreign language learners have problems in learning collocations. Likewise, Persianspeaking learners that reside in an EFL surrounding may face problems when learning collocations or more specifically verb-noun collocations. Perhaps, the inadequate knowledge of verb-noun collocations of Iranian learners of English is related to various features as they are not familiar with the structure of English collocations, and the negative transfer of language components such as collocations from Persian. Iranian students as most other foreign language learners in EFL classrooms do not have many occasions to encounter collocations in their day-to-day lives, it is supposed that they may normally resort to their first language when they run into collocations in EFL environments and in classrooms, because they learn individual words instead of collocations. Similarly, they are less exposed to the language in the society which makes them to produce errors that characterise them as non-native speakers even at the advance level. It was also detected that most Iranian teachers do not pay much attention to collocations in class. Nevertheless, pupils ought to have a very high capability to communicate or convey their thoughts in a clear way in English. This skill may reflect their capacity to manipulate verb-noun collocations in an appropriate and fluent manner.

Consequently, this study pursued to identify the significance of learner collocational competence in an EFL situation. In general, the focus was to explain whether Iranian learners might acquire verb-noun collocations explicitly through teaching and exposure to language during their learning time in classrooms. 


\section{LITERATURE REVIEW}

Verb-noun collocations are a problematical part of learning a second language or a foreign language; nonetheless, it is a fundamental constituent of communicative competence. A dominant portion of native speakers' communicative competence is collocational competence, which means English native speakers know words co-occurrence subconsciously. Additionally, any speech community has a set of idiomatic ways of uttering concepts in definite complete expressions and many phrase-frames. Hence, learning formulaic language may cause a great deal of problems for non-native speakers with deficient communicative competence.

Native speakers habitually employ collocations whether fixed or flexible (Prodromou, 2003). It is deliberated that the automation of collocation helps native speakers utilise "chunks" of language that are ready-made to express their messages fluently. Second language learners make non-native errors when communicate with native speakers. Firth (1968) defines collocations of a given word "as statements of habitual or customary places of that word in collocational order but not in any other contextual order and emphatically not in any grammatical order" (p. 181). He also claims that a collocation is a "mode of meaning" and "an abstraction at the syntagmatic level" (1957a). Furthermore, he spots that part of a word's meaning can be located in its collocate. He offers that words gain meaning from their co-occurrence in texts and proposes that a meaning should be scrutinised in four levels: the orthographic level, the phonological level, the grammatical level, and the collocational level. Firth's pioneering conception on collocations has moved researchers to concentrate not only on the paradigmatic level of collocations but also on the syntagmatic level of collocations.

Firth's conceptions are reiterated by neo-Firthians, the most eminent of these are McIntosh (1961), Halliday (1966), and Sinclair (1966). Halliday (1966) and Sinclair (1966) endeavoured to research collocations in the same way as grammar. They scrutinised lexis as a linguistic level in parallel with grammar. They recommended that lexical items are designated from lexical patterning and are indicated in grammatical items from a grammatical system that commenced to the grammatical structure. This concept advocates that a language is comprised of hundreds of thousands of lexical units. McIntosh (1961), moreover, proposed that the range of collocability of particular items can provide a way of distinguishing words from each other. For example, putrid and rancid are synonymous, but putrid collocates with fish and rancid with butter. Collocations that can collocate widely are normally restricted to certain patterns and are non-substitutable. For example, soft, mild, and gentle can all collocate with voice, breeze or soap, but each word has restricted collocations, such as soft water, soft drink, mild steel, gentle soap, etc. (McIntosh, 1961 cited in Mitchell, 1971, pp. 3569).

Second or foreign language learners cannot find any definite collocation rules to learn them; therefore, that is the chief cause why collocation has turned into one of the most problematic facets in learning English. The native English speaker unconsciously understands where and when to utilise the correct collocation deep-rooted in his lifetime's exercise of manipulating words in language chunks. Shehata (2008) remarks that the foreign language novice retains less experience and might frequently collocate words in such a way as to look odd to native speakers. Therefore, any formal educational systems need to formulate a plan in classroom to offer the collocational knowledge in an explicit and accessible manner to non-native speakers. In the status quo of a foreign language situation like Iran, collocational knowledge can be beneficial since it assists the students to enhance their communicative competence and strengthens their speech and writing.

\subsection{The Characteristics of Collocations}

There are numerous features for collocations; nevertheless, in this research, three central characteristics are argued. The first characteristic of collocations is their prefabrication and restriction (Biskup, 1992; Bolinger, 1968; Ellis, 2003; Howarth, 1998a; Lewis, 1993, 1997a; 1997b; Nattinger, 1980). To maintain this view, Bolinger (1968) explains collocation types as learned prefabs that are stored, retrieved, and produced automatically. For instance, if we inquire the child a definition "What is a hole?" The child will systematically say "a hole in the ground." This means that once the word "hole" is expressed, it is retrieved from the memory together with what it is associated with (p. 11). Cruse (1986), moreover, elucidates that collocational restrictions are co-occurrence restrictions and are arbitrary generations. As blonde collocates with human beings' hair but not that of hairy animals (p. 279). As Lewis (1997a; 1997b) appeals, "Collocation is arbitrary... this non-generalizability clearly indicates that we meet and store words in the prefabricated chunks..." (p. 26). 
The second characteristic is that of collocations cannot be substituted by other words. Bolinger (1976) indicated that the specific words in a collocation cannot be defined easily and be substituted by their synonyms. For instance, make a mistake cannot be paraphrased as *commit a mistake; take a risk cannot be replaced by *get a risk. Reinforcing the similar opinion, Cowie (1981) indicates that collocations integrate "common-core" verb clusters characteristic of daily life, such as clear the table and lay the table, and the firmness of collocations rarely can be exchanged by a synonym for the verb component, such as *empty the table and *prepare the table. Overall, collocations are prefabricated chunks with a definite amount of arbitrariness and non-substitution.

The final characteristic is the idiomaticity or non-idiomaticity of collocations that is debateable and has been extensively argued for decades. An idiom or idiomatic phrase, according to is "a combination of two or more words which function as a unit of meaning" (Cowie, Mackin, and MaCCaig, 1983, p. viii). Spears (2000) promotes this notion too and specifies, "all languages have phrases or sentences that cannot be understood literally. A phrase or sentence of this type is said to be idiomatic" (p. vii), for example, live through; have a rough time, and kick the bucket, etc. In the papers of collocations, some investigators have a tendency to categorise idioms or idiomatic phrases from collocations. Correspondingly, Bolinger (1976) ascertains the variances between idioms and collocations, and asserts that idiom meanings cannot be guessed from the meanings of their parts, whereas the meaning of collocations can be predicted from their parts. He claims that "collocations should be categorised distinctly from idioms or as a major sub-class [of idioms]" (p. 5). Biskup (1992) argues the dissimilarities in more depth and asserts that one of the characteristics of collocations is their non-idiomaticity and that the meaning of collocations is always clear. The result publicised that learners' knowledge of collocations does not boost in the same rate of their vocabulary knowledge. They declare that it is because collocation teaching has been basically overlooked in the EFL classroom and hence, students do not concentrate on acquiring collocations. Additionally, they accomplish that collocational knowledge is crucial for highest communication in English and denote that it is needless to teach those collocations that have meanings that can be recognised and paraphrased while learners can comprehend them easily. Issues affecting the acquiring verb-noun collocations are non-congruence of the structures between L1 and L2 and lack of enough exposure to the L2 collocations.

\subsection{Studies in Verb-Noun Collocations}

There are abundant academics studying learners' collocational knowledge; however, among them, Biskup's (1992) comparative study is outstanding and has been quoted very frequently. Her study highlighted lengthily lexical collocations in which verb-noun collocations were comprised. She discovered that students confronted a great deal of difficulties in translating verb-noun collocations from their L1 into English correctly if the types of verb were creation, activation (e.g. to reach a verdict) or eradication and nullification (e.g. to lift a blockade). Polish students were more inclined not to take risks on guessing answers. Nonetheless, German students endeavoured to utilise diverse techniques to infer the meaning of a collocation, if they did not know the English counterpart. Also, the result shows the fact that EFL teaching in Poland and Germany diverges and leads to diverse learning styles and attitudes. The Polish educational system asserts on accuracy whereas the Germans focusses on to fluency and communication.

Additionally, she located that Polish students depended more on their LI and executed more transfer errors whilst the German students considered strategies that are more innovative and committed other kinds of errors. Overall, both groups would construct alternatives regularly for the class of verbs. Regarding interference errors, Polish students who observed the distance between Polish and English committed more transfer errors or broadened L2 meanings on the foundation of the LI words. In contrast, the German students tended to produce errors resulting from assumed formal similarity (code switches, hybrids, and blends). Biskup presumes that generating native-like collocations in the learners' mental lexicon will decrease the struggle of exploiting collocations in language production.

Besides, alternative study executed by Bahns and Eldaw (1993) in which they gauged active knowledge of 15 English verb-noun lexical collocations. They employed a translation task and a cloze task as instruments, and the subjects were 58 advanced German learners. The result publicised that learners' collocational knowledge does not progress in a parallel way as their knowledge of vocabulary. They declare that this may happen because collocation instruction has been mostly disregarded in the EFL classroom, so learners do not concentrate on learning collocations. 
Furthermore, they determine that it is fundamental for complete use of English in communication and point out that it is necessary to teach those collocations which are different between L1ans L2.

Al-Zahrani (1998) exploited a new way and revealed that there was a substantial variance in subjects' performance consistent with their academic levels. Nesselhauf (2005), who illustrated that learners' L1 strongly affected their collocation productions, stressed Al-Zahrani's findings. Martyska (2004) also accomplished a study and the results concur with those gained by preceding researchers that most of collocational errors stemmed from negative LI transfer. The Martyska's study (2004) initiated that intermediate high school students discerned 55\% of all collocations in four different tasks, and verbnoun collocations appeared to be less difficult than other types of lexical collocations under examination for this group of subjects. Martyska also underlined the imperative role of the teacher and the textbooks in the process of second language teaching. Both Al-Zahrani's study and Martyska's study infer that when learners are exposed more to the target language and academic maturity may directly influence the acquisition of collocations.

Additionally, there are a few research on verb-noun collocations in Iran. Tajalli. (1994), and Morshali (1995) fulfilled a broad research on the learning of English lexical collocations by Iranian EFL learners. The results revealed that the Iranian EFL learners' knowledge of vocabulary was much better than their knowledge of collocations, and there was no significant relationship between the level of language proficiency and that of the knowledge of English collocations. Moreover, the Iranian students did not normally grasp collocations without formal teaching. To end, the number of collocational errors formed by the Iranian EFL learners underlined the requisite for formal teaching of collocations (1995: iv).

Bagherzadeh Hosseini and Akbarian's (2007) paper inspected the relationship between collocational competence and general language proficiency and scrutinised the go-togetherness of quantitative and qualitative characteristics of lexical knowledge. The results specified that there was a relationship between the collocation test and TOEFL and between the vocabulary section of TOEFL and the collocation test. They also established that it is crucial to teach collocation explicitly at the right time so that students might become aware of collocations.

Hsu (2002) opened a new path to study lexical collocations in the classroom situation by exploiting an experiment and revealed that underlining lexical collocations involved learners learning new collocations in the written and spoken discourse. Similarly, it assisted them to handle them in new and innovative techniques.

Bazzaz and Samad (2011) argued the relationship between collocational knowledge and the use of verb-noun collocations in writing stories since collocational knowledge differentiates native speakers and foreign or second language learners and is a major issue in productive skills especially writing. The results specified that there was a large positive relationship between knowledge of collocations and the use of verb-noun collocations in the stories.

Ebrahimi-Bazzaz, Samad, Ismi, and Nooreen, (2012) argued that there was a relationship between collocational competence and language proficiency. The results of the statistical analyses certified that there existed a high positive relationship between general language proficiency of learners and collocational competence. In 2014, they projected the relationship between verb-noun collocation proficiency and academic years. The results corroborated that there existed variances in the verb-noun collocations proficiency within each academic year and between the four academic years. In 2015, they estimated the use of verb-noun collocations in written discourse of Iranian learners. The results of the statistical analysis designated that there existed a significant difference in the use of lexical verb-noun collocations in written discourse both between and within the four academic years. Their results imply considerable development in verb-noun collocation proficiency. In another paper in 2015, they scrutinised verb-noun collocations in spoken discourse of Iranian EFL learners, and the statistical results verified that there existed a significant variance in the use of lexical verb-noun collocations in spoken discourse both between and within the four academic years. Additionally, the results specified that the use of verb-noun collocations grew considerably in spoken discourse..

\subsection{Pedagogical Aspect of Collocations}

Collocation acquisition is very noteworthy in second or foreign language learning because it makes speakers and writers to become fluent in both speaking and writing. The literature reviews have exhibited that learners have inadequate knowledge of collocations and that this is partly due to the 
lack of collocation instruction (Al-Zahrani, 1998; Bahns \& Eldaw, 1993; Farghal \& Obiedat, 1995; Gitsaki, Daigaku, \& Taylor, 1999; Liu, 2010). At the same time Lewis (1997a; 1997b) states, making learners aware of collocations and motivating them to search this territory and aids learners use of the language which they partly know better.

Correspondingly, Woolard (2000) reinforces the independence of language learners and considers that teachers ought to prepare learners with skills to assist them to progress their knowledge of collocations independently. He presents some approaches to make learners aware of collocations, and one of the overt techniques is through the choice of the miscollocations' students generate in their construction of language. Moreover, Woolard points out that highlighting collocations is imperative for language learning in class. The most essential issue is to provide students with research skills that empower them to realize major collocations by themselves, both in and outside the classroom. In other words, learners ought to be motivated to so that they might become responsible for their own learning and learning path whereas teachers act as facilitators in the class.

\subsection{The Present Research}

Webb and Kagimoto (2009) stated:

"most research carried out within the L2 classroom has also been largely descriptive in nature, concerned primarily with assessing the extent of learner knowledge of collocation and its influence on learner errors... research on vocabulary in an EFL context indicates that incidentally acquiring meaning for even relatively single-word items is a relatively slow process with learning dependent on the amount of input" (p. 57).

Their declaration claims that both a single word and multi-word vocabularies like verb-noun collocations may be better studied in classes if they are taught explicitly. There are not much research in how collocations can be learnt in Iran. The present study is designed to fill this gap by exploring the extent to which collocation learning can be enhanced by focussing and drawing students' attentions to them.

The present paper advances, progresses those above-mentioned research and attempts to accomplish the gap to investigate the effect of treatment in teaching verb-noun collocations to Iranian learners. It raises the following research questions:

- Does the teaching of verb-noun collocations have any effect on the improvement of students' collocational knowledge?

\section{Methodology}

\subsection{Participants}

Participants were chosen from a private language institute in Tehran. A total number of sixty female students were chosen from intermediate level. The youngest test taker was 18 and the oldest one was 22. Their first language was Persian and they were native speakers of Persian.

\subsection{Instrument}

The instruments of the present study were a demographic questionnaire, and a blank-filling collocation test. In the demographic questionnaire, subjects were requested to complete a questionnaire that was planned to elicit background information about them like name, age, and years of studying English. At the commencement of the study, the researcher prepared two English collocation tests based on the intermediate book of the instituted to determine the collocational level of the classes. Since they were researcher-made tests, they were subjected to a pilot study. To check validity, the tests were given to a couple of experienced language teachers at the institute. Their comments were applied in the drafts of the tests. To check reliability, the pre-test and the two posttests were given to a similar population. The reliability of the pre-test was proved to be 0.78 and that of the post test was 0.80 . Then they were administered to participants as the pre and post collocational proficiency tests. The final form of each test was composed of fifty item C-test. The result indicates that the Tests of Collocations were a reliable one; therefore, it could be employed to assess students' collocational knowledge. 


\subsection{Procedure}

The procedure of this study was carried out in two consecutive stages to demonstrate the steps taken in the study. The two groups were chosen based on convenient sampling, because the institute used its placement test to place students in different classes. A pre-test was administered to verify the participants' collocational level in the two groups before treatment phase and an Independent Sample t-test was performed to observe whether any variances was between the two groups. In the second stage, after ten sessions of the treatment, a post-test was administered to both groups. The English teacher was instructing both the control and experimental groups throughout the treatment.

The control group learned the new vocabulary via conventional techniques in the students' book. The teacher wrote the new words on the board, asked students to copy, and learned them. In the next session, the teacher inquired them and wrote a sentence for words. The experimental group was taught vocabulary by emphasising verb-noun collocations. The teacher wrote the words and their collocations on the board. Students were asked to copy them and for the next session, the teacher asked them and wrote a sentence for collocations.

\subsection{Data Analysis}

\subsubsection{Pre-Test Analysis}

To find the answer for the research question, verb-noun collocation test was administered to both groups as a pre-test, and an independent t-test was carried out on the two groups test scores. According to Table 1, the mean scores for the experimental and control groups on the pre-test were 54.366 and 54.21 respectively that resulted in a difference of 0.156 .

Table1. Descriptive statistics of the two groups on the collocation pre-test.

\begin{tabular}{|l|l|c|l|l|l|}
\hline & & $\mathrm{N}$ & Mean & Std. Deviation & Std. Error Mean \\
\hline \multirow{2}{*}{$\begin{array}{l}\text { Collocation } \\
\text { Test }\end{array}$} & control & 30 & 54.366 & 14.90772 & 2.72177 \\
\cline { 2 - 6 } & experimental & 30 & 54.521 & 11.14399 & 2.03460 \\
\hline
\end{tabular}

Table2. Comparison between variances and means of the two groups on the pretest.

\begin{tabular}{|l|l|l|l|l|l|l|}
\hline \multicolumn{2}{|c|}{} & \multicolumn{5}{l|}{ Levene's Test for Equality of Variances } \\
\cline { 3 - 7 } & F & Sig. & t & df & Sig. (2-tailed) \\
\hline \multirow{2}{*}{} & Equal variances assumed & 3.907 & .053 & -1.5 & 58 & .135 \\
\cline { 2 - 7 } & Equal variances not assumed & & & -1.5 & 54.3 & .135 \\
\hline
\end{tabular}

Since the significance value for Levene's test is less than $0.05(0.01<0.05)$, the variances of the two groups are not equal, and thus the second line of the table is reported. As can be seen from the table above, the significance level between the control and experimental groups with degree freedom of 58 and $t$ value of -1.5 was found to be 0.135 , which is not significant at 0.05 significance level. As the result stipulates, it was inferred that the two groups were homogeneous regarding collocation knowledge and therefore they could securely be assigned to control and experimental groups.

After ten weeks of intervention, both groups were presented a similar post-test. As Table 3 signifies, the mean score of experimental group was 52.54, which was greater than the mean score of control group, 47. There is 5.24 difference.

Table3. Descriptive statistics of the two groups on the collocation post-test.

\begin{tabular}{|l|l|c|l|l|l|}
\hline & & $\mathrm{N}$ & Mean & Std. Deviation & Std. Error Mean \\
\hline $\begin{array}{l}\text { Collocation } \\
\text { Test }\end{array}$ & control & 30 & 47 & 15.9 & 2.89788 \\
\cline { 2 - 6 } & experimental & 30 & 52.54 & 12.12 & 2.22046 \\
\hline
\end{tabular}

To realize whether the intervention was effective or not, the means of two groups were compared through a t-test.

Table4. Comparison between variances and means of the two groups on the posttest.

\begin{tabular}{|c|c|c|c|c|c|}
\hline & \multicolumn{5}{|c|}{ Levene's Test for Equality of Variances } \\
\hline & $\mathrm{F}$ & Sig. & $\mathrm{t}$ & $\mathrm{df}$ & Sig. (2-tailed) \\
\hline Equal variances assumed & 6.55 & 0.13 & -20.26 & 58 & 0.000 \\
\hline Equal variances not assumed & & & -2026 & 58.28 & 0.000 \\
\hline
\end{tabular}


As it has been shown in Table 4, the significance value for Levene's test which is less than 0.05 $(0.031<0.05)$, the variances of the two groups are not equal, and thus the second line of the table is reported. There was a statistically significant increase in the means of Collocation Test scores in control group $(\mathrm{M}=, 47, \mathrm{SD}=15.9$ to experimental $[\mathrm{M}=52.54, \mathrm{SD}=12.12, \mathrm{t}(29)=-20.26, \mathrm{p}<0.000]$; the difference between the two groups was located to be 0.000 which is highly significant at 0.05 level $(0.000<0.05)$. Therefore, by concerning that the mean of the experimental group was significantly higher than the control group, it could be inferred that the teaching of collocation was significant in enlightening Iranian EFL learners' collocational learning.

\section{ReSUlts AND DiscuSSION}

Concerning the research question, the results of the data attained from the experimental research were so conclusive that it can be established that teaching collocations assists students to learn collocations better than the classical technique. The results also exhibited that words were better learned by knowing their collocations.

In the current research, the experimental group accomplished much more superior than the control group in the post collocation test. It can assumed that teaching of vocabulary via collocations enhanced students' collocational proficiency levels in the experimental group while the same positive effect did not occur in the control group in which new vocabulary was taught by means of conventional techniques. Vocabulary teaching through collocation technique may aid learners to acquire the vocabulary items considerably better than the conventional techniques.

\section{Conclusion}

Many investigations have revealed that teaching collocations is advantageous to foreign language learners, the statistical results of paired t-test in my study indicated the intervention was effective enough to formulate a substantial variability between the experimental and control group. This may assist Iranian subjects to understand the differences between words and verb-noun collocations.

To sum up, the results of this study recommends that an essential constituent of language learning is collocational competence; nevertheless, Iranian learners of English may close their eyes to it because they are not emphasises in their classes. This problem results in poor communicative competence; consequently, they cannot communicate with native speakers. It even sometimes leads to misunderstanding. Even though many Iranians may have a high level of proficiency in knowing a lot of vocabulary and appropriate knowledge of grammar, their communicative competence might be far from that of the native speakers of English because of the lack of prefabricated chunks. Additionally, this paper recommends that Iranian learners may be aided to have less problems with English verbnoun collocations by teaching them in order to they can communicate effectively.

It can be deduced the results of this study have immediate implications for language learners that learning collocations is according to Lewis (2010), the whole language can be taught through collocations. The present paper also offers teachers with some suggestions to localise where complications with collocations exist with the aim of highlighting the problematic verb-noun collocations. The results also denotes that EFL teachers ought to instruct their students in an innovative way to encourage them to acquire and master the use of collocations.

\section{REFERENCES}

Aghbar. A. A. (1990).Fixed Expressions in Written Texts: Implications for Assessing Writing Sophistication. Paper presented at the meeting of the English Association of Pennsylvania State System Universities.

Al-Zahrani, M. S. (1998). Knowledge of English lexical collocations among male Saudi college students majoring in English at a Saudi university: Unpublished doctoral dissertation Indiana University of Pennsylvania., Pennsylvania.

Bahns, J., \& Eldaw, M. (1993). Should we teach EFL learners collocations? .System, 21(1), 101-114.

Bagherzadeh Hosseini, M . S. \& Akbarian, I. (2007). Language Proficiency and Collocational Competence. The Journal of Asia TEFL, 4(4), 35-58.

Bazzaz, F., \& Samad, A. (2011).The Use of Verb-noun Collocations in Writing Stories among Iranian EFL Learners. English Language Teaching, 4(3), 158-163. 
Biskup, D. (1992). L1 influence on learners' rendering of English collocations. In P. A. H. Bejoint (Ed.), Vocabulary and applied linguistics (pp.85-93). London: McMillan. Halliday, M. (1966).Lexis as a linguistic level. In C. Bazell, J. Catford, M. Halliday \& R. Robins (Eds.), In memory of J. R. Firth 148-162. London: Longman.

Bolinger, D. L. (1968).Aspects of Language. New York: Harcourt, Brace \& World, Inc.

Bolinger, D. L. (1976).Meaning and memory. Forum Linguisticum, 1(1), 1-14.

Cowie, A. P. (1981). The treatment of collocations and idioms in learners' dictionaries. Applied Linguistics, 2(3), 223.

Cowie, A. P., Mackin, R., \& MaCCaig, I. R. (1983).Oxford dictionary of current idiomatic

Ebrahimi-Bazzaz, F., Samad, A. A., bin Ismail, I. A., Noordin, N., (2012). Measuring Collocational Competence of Iranian Learners by Using C-test. The Iranian EFL Journal, 2, 227- 240.

Ebrahimi-Bazzaz, F., Samad, A. A., bin Ismail, I. A., \& Noordin, N. (2014) Verb-Noun Collocation Proficiency and Academic Years. International Journal of Applied Linguistics \& English Literature, 3(1), 152-162

Ebrahimi-Bazzaz, F., Samad, A. A., bin Ismail, I. A., \& Noordin, N. (2015). Verb-Noun Collocations in Written Discourse of Iranian EFL Learners. International Journal of Applied Linguistics and English Literature, 4(4), 186-191.

Ebrahimi-Bazzaz, F., Samad, A. A., bin Ismail, I. A., \& Noordin, N. (2015). Verb-Noun Collocations in Spoken Discourse of Iranian EFL Learners. International Journal of Applied Linguistics \& English Literature, 3(3), 41-50

Ellis, N. C. (2003). Constructions, chunking, and connectionism: The emergence of second language structure. The handbook of second language acquisition, 14, 63.

Farghal, M., \& Obiedat, H. (1995). Collocations: A neglected variable in EFL. IRAL International review of applied linguistics in language teaching, 33(4), 315-331.

Gitsaki, C., Daigaku, N. S., \& Taylor, R. P. (1999).English collocations and

their place in the EFL classroom.Available at: http://www.hum.nagoya- cu.ac.jp/ taylor/ publications/collocations.html.

Howarth, P. (1998a). Phraseology and second language proficiency. Applied Linguistics, 19(1), 24.

Hsu, J. U. (2002). Development of Collocational Proficiency in a Workshop on English for General Business Purposes for Taiwanese. Unpublished doctoral dissertation, Indiana University of Pennsylvania, Pennsylvania.

Lewis, M. (1993).The lexical approach: The state of ELT and a way forward. London: Language Teaching Publications.

Lewis, M. (1997a).Implementing the lexical approach: Putting theory into practice.. London: Language Teaching Publications.

Lewis, M. (1997b). Pedagogical implications of the lexical approach.In J. Coady and T. Huckin (Ed.), Second language vocabulary acquisition: A rationale for pedagogy, (p. 255). Cambridge: Cambridge University Press.

Lewis, M. (2000).Teaching collocation: Further developments in the lexical approach. London: Language Teaching Publications.

Lewis, M. (2010). Teaching collocation: Further developments in the lexical approach. TESL-EJ, 14(2).

Liu, C.P. (2010).Going Beyond Patterns: Involving Cognitive Analysis in the Learning of Collocations TESOL Quarterly, 44(1), 4-30(27).

Martyska, M. (2004). Do English language learners know collocations? Investigationes linguisticae, $1-12$.

McIntosh, M. (1961). Patterns and ranges. Language, 37(3), 325-337.

Morshali, F. (1995).“A Cross-Sectional Study of the Acquisition of English Lexical Collocations by Iranian EFL Learners. ”Unpublished M. A. Thesis. Shiraz Islamic Azad University.

Nattinger, J. R. (1980). A lexical phrase grammar for ESL.TESOL quarterly, 14(3), 337-344.

Nesselhauf, N. (2005). Collocations in a learner corpus: John Benjamins Publishing Company. 
Prodromou, L. (2003). Idiomaticity and the non-native speaker. English Today, 19(02), 42-48.

Sinclair, J. (1966). Beginning the study of lexis. In J. C. C. C Bazell, M. A. K. Halliday, and R. H. Robins: (Ed.), In Memory of J. R. Firth: Longman.

Mitchell, T. F. (1971). Linguistic 'goings-on': Collocations and other lexical matters arising on the syntagmatic record. Archivum Linguisticum, 2(1), 35-69.

Shehata, A. K. (2008). L1 Influence on the Reception and Production of Collocations by Advanced ESL/EFL Arabic Learners of English. Ohio University.

Spears, R. A. (2000).NTC's Compact English Dictionary: The Core Vocabulary for Learners: NTC Pub. Group.

Tajalli, G. (1994). Translatability of English and Persian collocations. Paper presented at the second conference on translation. Tabriz University, Tabriz.

Webb, S., \& Kagimoto, E. (2009). The effects of vocabulary learning on collocation and meaning. Tesol Quarterly, 55-77.

Woolard, G. (2000). Collocation-encouraging learner independence. Teaching collocation: Further developments in the lexical approach, 28-46. 